\title{
Wybrane zagadnienia antybiotykoterapii zakażeń bakteryjnych u chorych na nowotwory złośliwe
}

\author{
Łukasz R. Nowak
}

Zakażenia stanowią jeden z najważniejszych problemów współczesnej onkologii. Nie tylko są one jedną z najważniejszych przyczyn zgonów chorych na nowotwory złośliwe, ale również jednym z najczęstszych powikłań leczenia onkologicznego. Upośledzenie odporności związane najczęściej z chemioterapią oraz sama choroba nowotworowa predysponują pacjentów onkologicznych do zakażeń zarówno typowymi bakteriami, jak też i drobnoustrojami oportunistycznymi. Sprawia to, że leki przeciwdrobnoustrojowe są stosowane w dużych ilościach na oddziałach onkologicznych, a lekarze onkolodzy zmuszeni są nabyć biegłość w posługiwaniu się nimi. Niestety, w ostatnich latach daje się zaobserwować zjawisko narastania wśród bakterii antybiotykooporności, co bardzo utrudnia skuteczne leczenie zakażeń. Wielokrotnie donoszono o występowaniu szczepów bakterii opornych na wszystkie lub prawie wszystkie znane antybiotyki. Ponadto istotnym problemem stają się powikłania związane ze stosowaniem leków przeciwdrobnoustrojowych, w tym zakażenia Clostridium difficile. Wyniki badań pokazują, że prawidłowe prowadzenie antybiotykoterapii skutkuje nie tylko poprawą wyników leczenia chorych, ale również przekłada się na zmniejszenie zużycia tych leków i w konsekwencji może hamować narastanie antybiotykooporności wśród bakterii. Celem artykułu jest przybliżenie zasad prawidłowej antybiotykoterapii, ze szczególnym zwróceniem uwagi na informacje przydatne w praktyce onkologicznej oraz najnowsze osiągnięcia w tej dziedzinie. Zaprezentowano również informacje na temat zasad profilaktyki i leczenia gorączki neutropenicznej.

\section{Antibiotic therapy of bacterial infections in oncology}

Infections are among the most important problems of contemporary oncology. Not only are they responsible for a significant part of cancer mortality, but they are also frequent complications of cancer treatment. Immunosuppression, predominantly due to chemotherapy, predisposes oncological patients to infections, caused not only by the typical bacteria, but also by opportunistic microorganisms. This leads to widespread use of antimicrobial agents in oncological practice, and forces physicians taking care of patients with cancer to become experts in antibiotic therapy. Unfortunately, the efforts to combat infections have been hampered by the phenomenon of increasing antibiotic resistance among bacterial species. Multiple cases of infections with bacteria resistant to all, or almost all, known antibiotics have been described. Complications of antibiotic therapy, especially Clostridium difficile infections are also a growing concern. The results of studies confirm that proper antibiotic therapy not only improves cure rates of infections but also helps diminish antibiotic usage and therefore may contribute to a reduction of antibiotic resistance among bacteria. The aim of this paper is to disseminate knowledge about proper antimicrobial treatment with special emphasis on topics related to oncology and recent discoveries in this field.

Słowa kluczowe: antybiotyki, antybiotykooporność bakterii, zakażenia bakteryjne, nowotwory złośliwe Key words: antibiotics, antibiotic resistance, bacterial infections, neoplasms 


\section{Wstęp}

Zakażenia są jednym z najistotniejszych problemów współczesnej onkologii. U chorych na nowotwory występują liczne czynniki predysponujące do wystąpienia zakażenia. Infekcje są bezpośrednią przyczyną zgonu u znacznego odsetka chorych umierających z powodu nowotworów złośliwych [1]. Gorączka neutropeniczna należy do najczęstszych powikłań chemioterapii. Nierzadko wystąpienie zakażenia prowadzi do modyfikacji lub przerwania leczenia onkologicznego, zmniejszając szanse chorego na wyleczenie [2]. Z tego powodu oddziały onkologiczne przodują (oprócz oddziałów intensywnej terapii) w statystykach zużycia antybiotyków w szpitalach (w niektórych badaniach nawet $40 \%$ chorych hospitalizowanych w oddziałach onkologicznych otrzymuje antybiotyki), a lekarze onkolodzy bardzo często stają przed koniecznością zlecania leków przeciwdrobnoustrojowych [3,4]. Powszechne stosowanie antybiotyków nie pozostaje jednak bez konsekwencji. Nie tylko zwiększa się ryzyko infekcji bakteriami wieloopornymi, ale również ryzyko wystąpienia nadkażenia. Spośród zakażeń bezpośrednio związanych z antybiotykoterapią na pierwsze miejsce pod względem istotności wysuwa się zespół chorobowy wywoływany przez szczepy Clostridium difficile, produkujące toksyny A i B [5]. Ponieważ wiadomo, że nieprawidłowo prowadzona antybiotykoterapia nie tylko zmniejsza prawdopodobieństwo wyleczenia zakażenia, ale również sprzyja selekcji opornych bakterii i zwiększa koszty leczenia, wiedza na temat właściwego prowadzenia antybiotykoterapii jest szczególnie przydatna lekarzom, którzy opiekują się chorymi na nowotwory. Jest to istotne zwłaszcza dlatego, że leczenie zakażeń u chorych onkologicznych należy z wielu powodów do zagadnień trudnych [6]. Celem artykułu jest przybliżenie lekarzom klinicystom, którzy opiekują się chorymi na nowotwory, informacji na temat współczesnej antybiotykoterapii. Jest to szczególnie potrzebne w sytuacji, gdy w wielu szpitalach nie ma procedur antybiotykoterapii ani nie jest dostępna fachowa pomoc specjalisty zajmującego się antybiotykoterapią przy podejmowaniu trudnych decyzji terapeutycznych - czyli to, co w piśmiennictwie anglosaskim określane jest mianem antibiotic stewardship. Wykazano, że wprowadzenie takich działań prowadzi do poprawy skuteczności leczenia, zmniejszenia kosztów antybiotykoterapii, a także ograniczenia występowania szczepów wieloopornych [7] — jednego z najważniejszych problemów w leczeniu zakażeń.

\section{Przyczyny zwiększonego ryzyka występowania zakażeń u chorych onkologicznych}

Postępy w onkologii doprowadziły w przypadku wielu nowotworów do znacznego wydłużenia czasu życia chorych. Wiąże się to jednak ze znacznym zwiększeniem intensywności i długotrwałości leczenia onkologicznego, a co za tym idzie - upośledzeniem układu immunologicznego. Czynniki zwiększonego ryzyka wystąpienia zakażeń u chorych onkologicznych zestawiono $w$ tabeli I.

Spośród wszystkich chorych onkologicznych największe ryzyko zakażeń występuje w hematoonkologii, szczególnie wśród chorych poddawanych zabiegom przeszczepienia komórek krwiotwórczych [8]. W przypadku chorych na guzy lite ryzyko wystąpienia zakażenia jest największe w okresie neutropenii. W tych sytuacjach klinicznych powszechnie i w zgodzie z aktualną wiedzą stosuje się profilaktykę przeciwdrobnoustrojową [9].

Tabela I. Czynniki zwiększające ryzyko wystąpienia zakażeń u chorych na nowotwory złośliwe $[9,86,87]$

\begin{tabular}{|c|c|}
\hline Czynniki związane z chorobą nowotworową & Uwagi \\
\hline nowotwory układu krwiotwórczego & bezpośrednie upośledzenie czynności układu immunologicznego \\
\hline nowotwory głowy i szyi & uszkodzenie bariery śluzówkowej \\
\hline nowotwory układu moczowo-płciowego & uszkodzenie bariery śluzówkowej, utrudnienie w odpływie moczu, przetoki \\
\hline nowotwory oskrzeli & regionalna niedodma \\
\hline nowotwory jelita grubego & uszkodzenie bariery śluzówkowej, retencja stolca \\
\hline Czynniki związane z leczeniem przeciwnowotworowym & Uwagi \\
\hline neutropenia & przede wszystkim po chemioterapii \\
\hline zapalenie błony śluzowej & po radio- lub chemioterapii \\
\hline leki immunosupresyjne & $\begin{array}{l}\text { najczęściej kortykosteroidy, leki immunosupresyjne stosowane w zapobieganiu } \\
\text { reakcjom odrzuceniowym }\end{array}$ \\
\hline leki celowane & zwłaszcza stosowane w hematoonkologii \\
\hline asplenia & $\begin{array}{l}\text { po zabiegu chirurgicznym, napromienianiu, w przebiegu choroby przeszczep } \\
\text { przeciwko gospodarzowi (GvHD) }\end{array}$ \\
\hline przebyte zabiegi chirurgiczne & $\begin{array}{l}\text { upośledzenie odporności w bezpośrednim okresie okołooperacyjnym, możliwe } \\
\text { pooperacyjne anatomiczne lub czynnościowe czynniki zwiększające ryzyko zakażeń } \\
\text { (np. wyłonione przetoki) }\end{array}$ \\
\hline dostępy żylne i porty do chemioterapii & do żył centralnych i obwodowych, dootrzewnowe \\
\hline
\end{tabular}

GvHD (graft versus host disease) — choroba przeszczep przeciwko gospodarzowi 
Oprócz profilaktyki z użyciem leków przeciwdrobnoustrojowych bardzo ważną rolę w zapobieganiu zakażeniom u chorych na nowotwory złośliwe odgrywają szczepienia ochronne. Aktualnie zaleca się szczepienie chorych na nowotwory przeciwko grypie, Streptococcus pneumoniae, Neisseria meningitidis, Haemophilus influenzae typu B oraz WZW typu B [10-12]. Szczepienia ochronne są niezwykle istotne u osób po anatomicznej lub czynnościowej splenektomii, u których ryzyko zakażenia spowodowanego przez bakterie otoczkowe jest istotnie zwiększone. Oprócz szczepień zazwyczaj zaleca się dodatkowo w tej grupie chorych długotrwałą profilaktykę antybiotykową z użyciem penicyliny, przez całe życie u chorych w immunosupresji i przez 2 lata u pozostałych chorych poddanych splenektomii, choć opinie na ten temat są sprzeczne [13-15].

\section{Leczenie zakażeń bakteryjnych}

Jeżeli u chorego wykryto lub podejrzewa się zakażenie bakteryjne, istnieją wskazania do zastosowania antybiotykoterapii. W zależności od tego, czy podstawą do zastosowania leku przeciwdrobnoustrojowego jest wynik badania mikrobiologicznego, zawierający informację na temat drobnoustroju i lekowrażliwości, czy też tylko objawy kliniczne lub wyniki badań dodatkowych, antybiotykoterapię dzieli się na empiryczną i celowaną.

Podstawowe zasady racjonalnej antybiotykoterapii polegają na:

- ograniczeniu leczenia do zakażeń o charakterze bakteryjnym,

- dążeniu do pełnej identyfikacji drobnoustroju patogennego wraz z oznaczeniem antybiotykooporności,

- stosowaniu antybiotyku, który jest skuteczny w danej sytuacji klinicznej,

- dawkowaniu leku w taki sposób, by osiągnąć odpowiednie jego stężenie w miejscu zakażenia,

- stosowaniu antybiotyku o możliwie najwęższym spektrum aktywności,

- regularnej ocenie skuteczności i zasadności prowadzenia antybiotykoterapii.

\section{Antybiotykoterapia empiryczna}

Zakażenia u chorych na nowotwory, zwłaszcza będących w okresie neutropenii, często przebiegają gwałtownie. W takiej sytuacji ważne jest szybkie rozpoczęcie antybiotykoterapii. Wyniki badań wskazują, że nawet niewielkie, liczone w godzinach opóźnienie podania pierwszej dawki antybiotyku istotnie pogarsza rokowanie chorych w sepsie [16]. W przypadku gorączki neutropenicznej przebiegającej bez objawów wstrząsu septycznego dane na temat wpływu opóźnienia w antybiotykoterapii na rokowanie są niejednoznaczne [17]. Zaleca się pobranie materiału do badań mikrobiologicznych przed rozpoczęciem antybiotykoterapii, o ile to możliwe [18].
Wybierając lek do antybiotykoterapii empirycznej, warto oprzeć się na opublikowanych wytycznych poświęconych leczeniu określonego rodzaju zakażenia. W przypadku gorączki neutropenicznej mogą to być na przykład wytyczne Infectious Diseases Society of America (IDSA) lub European Society for Medical Oncology (ESMO) [18, 19]. Bardzo ważną rolę odgrywa też znajomość flory własnej oddziału lub też regionu, w którym się pracuje. Zarówno dominujące patogeny, jak i profile antybiotykooporności różnią się znacznie pomiędzy oddziałami i regionami geograficznymi. W przypadku gdy prowadzi się antybiotykoterapię empiryczną, należy dążyć do ustalenia wiarygodnego rozpoznania mikrobiologicznego oraz próby wykluczenia nieinfekcyjnych przyczyn objawów, na przykład gorączki u chorego z neutropenią. W przypadku uzyskania wyniku badania mikrobiologicznego $z$ antybiogramem można podjąć antybiotykoterapię celowaną. Jeżeli pierwotnie stosowano empirycznie antybiotyki o szerokim spektrum aktywności, należy zawsze rozważyć, czy nie ma możliwości zmiany antybiotyku na inny, charakteryzujący się węższym spektrum działania. Takie postępowanie nazywa się deeskalacją antybiotykoterapii i uważa się powszechnie, że pozwala ono między innymi ograniczyć narastanie lekooporności wśród drobnoustrojów oraz zmniejszyć zaburzenia we florze własnej chorego powodowane przez antybiotykoterapię [20]. Potwierdzono bezpieczeństwo deeskalacji antybiotykoterapii u chorych z ciężką sepsą w przebiegu neutropenii [21].

\section{Antybiotykoterapia celowana}

Aktualnie laboratoria mikrobiologiczne w Polsce posługują się, w celu ujednolicenia metodyki wykonywania oznaczeń i raportowania wyników badań, wytycznymi European Committee on Antimicrobial Susceptibility Testing (EUCAST), których implementację w Polsce koordynuje Krajowy Ośrodek Referencyjny do spraw Lekowrażliwości Drobnoustrojów (KORLD). Na stronie internetowej KORLD (www.korld.edu.pl) można znaleźć tłumaczenia na język polski aktualnych zaleceń odnośnie wykonywania oznaczeń, oraz eksperckie zasady interpretacji wyników badań lekowrażliwości. Aktualne zasady podawania wyników zostały opracowane w taki sposób, by jak najbardziej ułatwić lekarzom interpretacje wyników, dlatego często opatrzone są one komentarzami na przykład na temat mechanizmów oporności wykrytych u bakterii czy też naturalnych oporności izolatów. Należy pamiętać, że wartości graniczne do określania, czy bakteria jest oporna na dany antybiotyk, zostały opracowane w oparciu o stosowanie dużych dawek antybiotyków, czasem większych niż typowo stosowane w warunkach klinicznych [22].

Wiedza o skuteczności antybiotyku stosowanego w leczeniu zakażenia powinna wynikać nie tylko z wyniku badania oporności drobnoustroju na antybiotyki, ale również opierać się na wynikach badań klinicznych. Skuteczność antybioty- 
Tabela II. Istotne parametry charakteryzujące najczęściej stosowane antybiotyki (opracowano na podstawie [88-92])

\begin{tabular}{|c|c|c|}
\hline & Działanie $^{A}$ & Parametr określający aktywność ${ }^{\mathrm{B}}$ \\
\hline pochodne $\beta$-laktamowe: & bakteriobójcze & $\mathrm{T}>\mathrm{MIC}$ \\
\hline \multicolumn{3}{|l|}{ - penicyliny i pochodne } \\
\hline \multicolumn{3}{|c|}{ — cefalosporyny i cefamycyny } \\
\hline \multicolumn{3}{|l|}{ - monobaktamy } \\
\hline \multicolumn{3}{|l|}{ - karbapenemy } \\
\hline glikopeptydy & bakteriobójcze & $\mathrm{T}>\mathrm{MICC}$ \\
\hline fluorochinolony & bakteriobójcze & $\mathrm{C}_{\max }>\mathrm{MIC}$ \\
\hline aminoglikozydy & bakteriobójcze & $\mathrm{C}_{\max }>\mathrm{MIC}$ \\
\hline tetracykliny i glicylocykliny & bakteriostatyczne & AUC $>$ MIC \\
\hline linezolid (oksazolidynon) & bakteriostatyczne & $\mathrm{T}>\mathrm{MIC}$ \\
\hline makrolidy/linkozamidy & bakteriostatyczne & $\mathrm{T}>\mathrm{MIC}$ \\
\hline trimetoprim/sulfometoksazol & bakteriobójcze & $\mathrm{C}_{\max }>\mathrm{MIC}$ \\
\hline kolistyna (polimyksyny) & bakteriobójcze & $\mathrm{AUC}>\mathrm{MIC}$ \\
\hline metronidazol & bakteriobójcze & $\mathrm{C}_{\max }>\mathrm{MIC}$ \\
\hline
\end{tabular}

T > MIC — czas utrzymywania się stężenia większego od minimalnego stężenia hamującego wzrost,

AUC > MIC — wielkość pola pod wykresem stężenia od czasu przekraczające wartość MIC — antybiotyki,

$\mathrm{C}_{\max }>\mathrm{MIC}$ - stosunek największego osiągniętego stężenia do wartości MIC,

Avide uwagi w tekście,

${ }^{B}$ dostępne dane $z$ literatury nie są zgodne co do tego parametru dla wielu antybiotyków,

Cniektórzy autorzy uważaja, że właściwsze jest uznanie AUC > MIC za decydujący parametr [93].

koterapii zależy przede wszystkim od osiągnięcia odpowiedniego stężenia antybiotyku w miejscu zakażenia. Niektóre antybiotyki nie osiągają stężeń terapeutycznych we wszystkich narządach. I tak na przykład spośród chinolonów nowej generacji moksyfloksacyna, w przeciwieństwie do lewofloksacyny, nie osiąga stężeń terapeutycznych w moczu [23].

\section{Podział antybiotyków ze względu na uwarunkowania farmakodynamiczne}

Antybiotyki, ze względu na uwarunkowania farmakodynamiczne, dzieli się na 3 grupy (vide tab. Il):

- antybiotyki, których skuteczność zależy od tego, przez jaki czas stężenie jest większe od najmniejszego stężenia hamującego wzrost bakterii (MIC — minimal inhibitory concentration). W przypadku antybiotyków należących do tej grupy korzystne jest częstsze podawanie mniejszych dawek bądź też stosowanie wlewów ciągłych (choć dowody na ten temat są dość słabej jakości i nie udało się na razie przekonywająco potwierdzić tego zjawiska w badaniach z randomizacją) $[24,25]$. Wyjątkiem od tej zasady są leki, których farmakokinetyka umożliwia utrzymywanie się wysokiego stężenia w osoczu (i miejscu zakażenia) pomimo rzadszego dawkowania (na przykład ceftriakson). Leki z tej grupy cechuje praktycznie całkowity brak efektu poantybiotykowego (czyli utrzymywania się hamującego wzrost bakterii działania pomimo obniżenia stężenia antybiotyku poniżej wartości MIC [26]). Przy okazji omawiania tej grupy antybiotyków warto wspomnieć o zdecydowanie najczęściej stosowanym dożylnie w polskich (i nie tylko polskich) szpitalach antybiotyku - amoksycylinie z kwasem klawulanowym [27, 28]. Jest to również antybiotyk o aktywności zależnej od czasu utrzymywania się stężenia powyżej MIC, jednak przy typowym dawkowaniu (3 razy na dobę po 1,2 g), ze względu na bardzo krótki okres półtrwania (poniżej 1 godziny zarówno dla amoksycyliny, jak i klawulanianu), u większości chorych nie udaje się osiągnąć założonego czasu utrzymywania się stężenia antybiotyku powyżej MIC (dla amoksycyliny jest to 40\%) [29], przez co leczenie może być nieskuteczne. Uwagi te nie mają zastosowania dla amoksycyliny z kwasem klawulanowym podawanych doustnie, gdyż w tym przypadku farmakokinetyka jest bardziej korzystna [30];

- antybiotyki, których skuteczność zależy od stosunku największego osiągniętego stężenia do wartości MIC. W przypadku antybiotyków z tej grupy korzystniejsze jest stosowanie większych dawek w rzadszych odstępach czasu. Antybiotyki z tej grupy wykazują zaznaczony efekt poantybiotykowy. Przedstawicielami tej grupy antybiotyków są na przykład aminoglikozydy [31]. Takie zachowanie antybiotyków aminoglikozydowych stało się podstawą do opracowania dawkowania raz dziennie tych leków i to właśnie takie dawkowanie jest podstawą do oznaczania lekowrażliwości drobnoustrojów zgodnie z zaleceniami EUCAST [22]. Wyniki badań klinicznych wskazują, że dawkowanie aminoglikozydów raz dziennie cechuje się lepszą lub przynajmniej nie gorszą skutecznością w porównaniu z dawkowaniem 
tradycyjnym, przy prawdopodobnie podobnym ryzyku nefrotoksyczności i ototoksyczności [32]. Chociaż istnieją dane uzasadniające takie dawkowanie również u chorych z gorączką neutropeniczną, to nie jest to postępowanie powszechnie akceptowane w tej sytuacji klinicznej i stoi w sprzeczności z niektórymi zapisami charakterystyk produktów leczniczych antybiotyków aminoglikozydowych [33, 34];

- antybiotyki, których skuteczność zależy od wielkości pola pod wykresem stężenia od czasu. Jest to grupa o właściwościach pośrednich pomiędzy dwoma pozostałymi grupami. Leki należące do tej grupy charakteryzuje efekt poantybiotykowy o zróżnicowanym natężeniu.

Omówiony powyżej podział, choć powszechnie przyjęty w literaturze, nie ma charakteru bezwzględnego. Niektórzy autorzy uważają, że prezentowane grupy stanowią tylko ekstrema pewnego continuum, a skuteczność leczenia przeciwdrobnoustrojowego zależy zawsze zarówno od osiągniętych stężeń, jak i czasu ich utrzymywania się powyżej pewnej wartości, tyle że w przypadku różnych antybiotyków istotniejszy jest bądź to jeden, bądź drugi parametr [35].

Ustalając dawkę początkową antybiotyku, należy rozważyć, zwłaszcza u chorych w ciężkim stanie ogólnym, zastosowanie zwiększonej dawki nasycającej. Wynika to z faktu, że chorych na przykład w sepsie lub z ciężkimi zakażeniami cechuje istotne zwiększenie objętości dystrybucji, współistniejące nierzadko ze zwiększeniem klirensu nerkowego [36].

Decyzja o zakończeniu leczenia przeciwdrobnoustrojowego powinna opierać się na zaleceniach renomowanych towarzystw naukowych. Istnieją dowody na przydatność oznaczania markerów biochemicznych stanu zapalnego, przede wszystkim prokalcytoniny, w podejmowaniu decyzji o zakończeniu leczenia [37].

\section{Podział antybiotyków ze względu na zdolność do zabijania komórek bakteryjnych}

Antybiotyki dzieli się na bakteriobójcze (bezpośrednio zabijają komórki bakteryjne) i bakteriostatyczne (w obecności skutecznego stężenia takiego leku bakterie nie namnażają się). Podział ten również nie ma charakteru bezwzględnego — rodzaj aktywności może zależeć na przykład od osiągniętego stężenia leku. Ponadto niektóre antybiotyki mogą wykazywać działanie bakteriobójcze wobec jednych szczepów bakterii, a bakteriostatyczne wobec innych (na przykład glikopeptydy wykazują działanie bakteriobójcze wobec gronkowców, a bakteriostatyczne wobec paciorkowców z rodzaju Enterococcus) [38]. U chorych w ciężkim stanie i neutropenii przesłanki teoretyczne uzasadniają preferencyjne stosowanie antybiotyków o działaniu raczej bakteriobójczym niż bakteriostatycznym. Brak jest jednak jednoznacznych dowodów na przewagę takiego postępowania pochodzących z badań klinicznych [39].

\section{Łączne stosowanie leków przeciwdrobnoustrojowych}

Stosowanie naraz więcej niż jednego leku przeciwdrobnoustrojowego jest praktyką dość powszechną, zwłaszcza podczas leczenia ciężkich zakażeń. Cele takiego postępowania mogą być dwojakie: rozszerzenie spektrum aktywności mikrobiologicznej i wzmocnienie działania bakteriobójczego (także po to, by uniknąć selekcji drobnoustrojów opornych na jeden ze stosowanych antybiotyków). Podejmując decyzję o zastosowaniu dwóch antybiotyków, należy pamiętać, że interakcje farmakodynamiczne pomiędzy lekami przeciwdrobnoustrojowymi są niezwykle skomplikowane. W zależności od tego, czy sumaryczna skuteczność leczenia łączonego jest większa czy też mniejsza od skuteczności poszczególnych leków stosowanych oddzielnie, rozróżnia się antagonizm, działanie addytywne i synergizm (działanie supraaddytywne). W antybiotykoterapii typowym przykładem takiego zjawiska jest synergizm pomiędzy aminoglikozydami i antybiotykami $\beta$-laktamowymi. Aminoglikozydy są nieskuteczne w monoterapii zakażeń spowodowanych przez paciorkowce z rodzaju Enterococcus, lecz w połączeniu $z$ antybiotykami $\beta$-laktamowymi nabierają właściwości bakteriobójczych wobec tej grupy drobnoustrojów (o ile oczywiście nie występują szczególne mechanizmy oporności, uniemożliwiające wystąpienie takiego zjawiska, na przykład oporność na gentamycynę wysokiego stopnia (HLGR - high level gentamycin resistance). Istnieją dane sugerujące występowanie antagonizmu na przykład pomiędzy antybiotykami hamującymi syntezę białka a antybiotykami upośledzającymi syntezę DNA [40], czy też pomiędzy tetracyklinami a antybiotykami $\beta$-laktamowymi (przy czym dane na temat antagonizmu tetracyklin i antybiotyków $\beta$-laktamowych są sprzeczne, niektórzy autorzy wykazywali wręcz synergistyczne działanie takiego połączenia [41]).

Pomimo powszechnego stosowania antybiotykoterapii skojarzonej brak jest w wielu sytuacjach klinicznych (w tym w gorączce neutropenicznej i sepsie) wiarygodnych dowodów na większą od monoterapii skuteczność takiego postępowania, i zawsze należy rozważyć, oprócz spodziewanych korzyści, również możliwe działania niepożądane [42, 43].

\section{Oporność bakterii na antybiotyki}

Oporność bakterii na antybiotyki może mieć charakter naturalny lub też nabyty. Naturalna oporność oznacza, że określony gatunek bakterii jest zawsze niewrażliwy na pewien antybiotyk lub też grupę antybiotyków. W takiej sytuacji nie wykonuje się badania wrażliwości patogenu na ten antybiotyk. Najczęstszą przyczyną występowania naturalnej oporności jest mała przepuszczalność ściany bakterii dla leku lub też obecność mechanizmu czynnie usuwającego lek z komórki bakteryjnej. Naturalna oporność jest szczególnym problemem w przypadku bakterii Gram- 
-ujemnych. Ściana bakterii Gram-ujemnych jest w ogóle nieco mniej przepuszczalna dla antybiotyków w porównaniu ze ścianą bakterii Gram-dodatnich. Niektóre pałeczki Gram-ujemne, na przykład Acinetobacter baumanii lub Stenotrophomonas maltophila, są naturalnie niewrażliwe na większość dostępnych antybiotyków [44, 45]. Staje się to szczególnym problemem, gdy u takiej bakterii pojawiają się dodatkowo mechanizmy oporności nabytej. Oporność nabyta polega najczęściej bądź to na pojawieniu się enzymów zdolnych do modyfikacji lub rozkładu cząsteczki antybiotyku, bądź też na mutacji genetycznej modyfikującej miejsce wiązania antybiotyku w komórce bakteryjnej, albo też na uruchomieniu przez bakterię mechanizmów czynnego usuwania leku z komórki (za to zjawisko odpowiadają białka podobne do pomp usuwających chemioterapeutyki z komórek nowotworowych, które są w części przypadków odpowiedzialne za występowanie oporności na chemioterapię) $[46,47]$. Synteza enzymów odpowiedzialnych za rozkładanie antybiotyku była historycznie pierwszym opisanym mechanizmem antybiotykooporności - już kilka lat po wprowadzeniu do leczenia penicyliny [48]. Przemysł farmaceutyczny podjął próbę wprowadzenia do leczenia nowych preparatów antybiotyków — opornych na rozkład przez enzymy lub też zawierających w składzie inhibitor enzymu, jednak z biegiem lat bakterie zaczęły wytwarzać nowe rodzaje enzymów, zdolne rozkładać nowe klasy antybiotyków bądź też odporne na inhibitory, na przykład $\beta$-laktamazy o rozszerzonym spektrum substratowym (ESBL - extended spectrum $\beta$-lactamases), rozkładające wszystkie dostępne antybiotyki $\beta$-laktamowe poza karbapenemami [49]. Aktualnie istotnym problemem klinicznym są pałeczki Gram-ujemne wytwarzające karbapenemazy i metalobetalaktamazy (MBL) - często zdolne do rozkładania wszystkich antybiotyków $\beta$-laktamowych, których występowanie stwierdzono już praktycznie na całym świecie, w tym w Polsce $[50,51]$. Niepokojąca jest możliwość przekazywania genów oporności pomiędzy szczepami, a nawet gatunkami bakterii. Geny te często znajdują się na ruchomych elementach genetycznych. Nierzadko na jednym plazmidzie znajduje się klika genów odpowiedzialnych za powstawanie oporności na antybiotyki należące do różnych klas, i przeniesienie takiego plazmidu sprawia, że bakteria od razu staje się wielooporna. Istotnym problemem jest też występowanie oporności indukowanej. W przypadku indukowanych mechanizmów oporności w komórce znajdują się geny kodujące odpowiednie białka, lecz nie ulegają one ekspresji, dopóki w środowisku nie znajdzie się antybiotyk. Przykładem takiej oporności jest obecność genów kodujących $\beta$-laktamazy chromosomalne z grupy AmpC u bakterii z rodzajów Enterobacter, Serratia, Morganella, Providencia, Pseudomonas i Escherichia. Enzymy te mają zdolność do rozkładania prawie wszystkich antybiotyków $\beta$-laktamowych, poza karbapenemami i cefalosporynami
IV generacji. Pod wpływem antybiotyków $\beta$-laktamowych może dojść do derepresji genów kodujących AmpC lub też do selekcji mutantów z derepresorowanym genem [52,53]. Podobne mechanizmy występują też na przykład dla makrolidów, streptogramin i linknozamidów (indukowalny mechanizm $M S_{B^{\prime}}$ występujący na przykład u ziarenkowców Gram-dodatnich) [54].

Bardzo ważny mechanizm oporności występuje u gronkowców i jest związany z mutacją białek wiążących penicylinę, w wyniku czego bakterie te stają się oporne na wszystkie antybiotyki $\beta$-laktamowe, w tym połączenia z inhibitorami $\beta$-laktamaz [55]. Gronkowce posiadające taki mechanizm oporności określa się jako metycylinooporne, najczęściej akronimami: MRSA - metycylinooporny Staphylococcus aureus i MRCoNS - metycylinooporne gronkowce koagulazo-ujemne. W leczeniu zakażeń tymi bakteriami można stosować antybiotyki z innych grup niż $\beta$-laktamowe (przede wszystkim glikopeptydy — wankomycynę i teikoplaninę, linezolid, czasem kotrimoksazol). Dla odróżnienia szczepy nieposiadające mechanizmu metycylinooporności określa się akronimami: MSSA — metycylinowrażliwy Staphylococcus aureus i MSCoNS - metycylinowrażliwe gronkowce koagulazo-ujemne. W przypadku gronkowców metycylinowrażliwych wysoką skuteczność zachowują penicyliny przeciwgronkowcowe, na przykład kloksacylina i cefalosporyny I generacji, na przykład cefazolina. Dopiero niedawno udało się zsyntetyzować i wprowadzić na rynek antybiotyk $\beta$-laktamowy zdolny do przełamania oporności na metycylinę - cefalosporynę o nazwie ceftarolina. Wyniki badań nad skutecznością kliniczną tego leku są obiecujące [56, 57].

Oprócz zjawiska pełnej oporności opisywane jest w literaturze również niepokojące zjawisko powolnego podnoszenia się wartości MIC glikopeptydów i linezolidu, przede wszystkim dla gronkowców (MIC creep) [58].

Opracowywanie nowych antybiotyków, zdolnych do zwalczania wieloopornych bakterii, napotyka na znaczne trudności $[59,60]$. W ostatnich latach na rynku pojawiło się zaledwie kilka takich preparatów, pomimo wdrażania inicjatyw mających promować badania nad nowymi antybiotykami (na przykład program 10 ×'20 - 10 nowych leków przeciwdrobnoustrojowych do 2020 prowadzony w USA) [61]. Z drugiej strony oporność izolatów bakteryjnych spotykanych w warunkach klinicznych narasta w sposób szybki, prowadząc do sytuacji, w której całe klasy antybiotyków stają się w pewnych regionach świata mało przydatne klinicznie [62]. Przyczyny tego zjawiska są różnorodne, jednak przyjmuje się, że do najważniejszych należy nadużywanie antybiotyków, nie tylko w medycynie [48]. Leki przeciwdrobnoustrojowe są bowiem powszechnie stosowane w rolnictwie (zwłaszcza w USA), w celu ochrony zwierząt przed zakażeniami, dla pobudzenia wzrostu zwierząt hodowlanych, a nawet do opryskiwania owoców [63]. 
Tabela III. Antybiotyki, które zazwyczaj nie wymagają modyfikacji dawki w niewydolności nerek (opracowano na podstawie [35, 94])

\begin{tabular}{l}
\hline Nazwa antybiotyku \\
\hline ceftriakson \\
kloksacylina \\
klindamycyna \\
linezolid \\
moksyfloksacyna \\
tygecyklina \\
azytromycyna
\end{tabular}

Doświadczenie kliniczne w stosowaniu u chorych z ciężką niewydolnością nerek większości z nowych leków zawartych w tej tabeli jest ograniczone, dlatego producenci zalecają ostrożność.

\section{Dawkowanie leków przeciwdrobnoustrojowych w niewydolności nerek}

Chorzy na nowotwory są grupą, w której zarówno ostra, jak i przewlekła niewydolność nerek występują szczególnie często. Szacuje się, że cechy przewlekłego uszkodzenia występują u 15-50\% chorych na nowotwory, a prawdopodobieństwo wystąpienia ostrej niewydolności nerek wynosi 15-45\% w ciągu roku [35]. W przypadku chorych z niewydolnością nerek właściwe dobranie dawki antybiotyku jest szczególnie trudne. Z jednej strony zastosowanie dawki zbyt małej może skutkować nieskutecznością leczenia, zdrugiej zaś, w przypadku zastosowania dawki standardowej spowolnienie eliminacji leku lub jego metabolitów może narazić chorego na wystąpienie powikłań. Istnieje grupa leków przeciwdrobnoustrojowych, których eliminacja jest niezależna (lub też prawie niezależna) od wydolności nerek. Leki te zestawiono w tabeli III. W przypadku leków eliminowanych przez nerki konieczne jest modyfikowanie dawki w zależności od klirensu kreatyniny bądź też oszacowań wartości tego parametru dokonywanych na podstawie pomiarów stężenia kreatyniny w surowicy krwi. W takim przypadku należy jednak brać pod uwagę również ograniczenia związane z niedokładnością samego oszacowania [64]. Ponadto w ostrej niewydolności nerek zmiany stężenia kreatyniny mogą oddawać pogorszenie czynności nerek ze znacznym opóźnieniem. Modyfikacja dawki nie powinna jednak zasadniczo dotyczyć dawki początkowej, tak aby uzyskać pożądany stopień wysycenia [35]. Szczegółowe zasady dawkowania poszczególnych antybiotyków w niewydolności nerek wykraczają poza ramy tego artykułu. W praktyce można oprzeć się na informacjach zawartych w charakterystykach produktów leczniczych lub też skorzystać z opracowanej przez nefrologów z Uniwersytetu wUlmstronyinternetowejhttp://www.uni-ulm.de/nepharm/, która - oprócz danych na temat dawkowania - zawiera istotne parametry farmakokinetyczne leków przeciwdrobnoustrojowych.

\section{Interakcje antybiotyków z lekami powszechnie stosowanymi w onkologii}

Lista potencjalnych interakcji lekowych związanych ze stosowaniem antybiotyków jest bardzo obszerna. W praktyce klinicznej nie obserwuje się ich jednak tak często. Potwierdzają to również wyniki badań przeprowadzone u chorych na nowotwory złośliwe [65], w których interakcje z lekami przeciwdrobnoustrojowymi stanowiły niewielki odsetek wszystkich potencjalnych interakcji lekowych wykrytych u chorych onkologicznych. Spośród często stosowanych u chorych onkologicznych antybiotyków należy zwrócić uwagę na:

- leki metabolizowane przy udziale cytochromu P450, na przykład erytromycynę, klarytromycynę czy też ciprofloksacynę. Wiele leków stosowanych powszechnie w onkologii (na przykład tamoksyfen lub cyklofosfamid) jest również metabolizowanych przez ten enzym. Interakcje związane z hamowaniem lub indukowaniem izoenzymów cytochromu P450 są często trudne do przewidzenia w warunkach klinicznych, gdyż istnieje znaczna zmienność genetyczna tego układu enzymatycznego w populacji [66]. Na stronie internetowej Wydziału Medycznego Uniwersytetu Indiana (USA) znajduje się wygodna w użyciu tabela interakcji lekowych związanych z metabolizmem przez cytochrom P450 - http:// medicine.iupui.edu/clinpharm/ddis/main-table/,

- linezolid, który hamuje oksydazę monoaminową, przez co może prowadzić do wystąpienia zespołu serotoninergicznego podczas równoczesnego stosowania z niektórymi lekami przeciwdepresyjnymi, ale również na przykład tramadolem lub petydyną [67, 68],

- ko-trimoksazol, wykazujący liczne interakcje lekowe, przede wszystkim z lekami stosowanymi w leczeniu nadciśnienia tętniczego (równoczesne stosowanie u chorych w starszym wieku ko-trimoksazolu z inhibitorami konwertazy lub spironolaktonem wiąże się prawdopodobnie ze zwiększeniem ryzyka nagłego zgonu) i antagonistami witaminy K [69-71],

- antybiotyki o działaniu nefrotoksycznym (przede wszystkim aminoglikozydy, wankomycyna, kolistyna) mogą wykazywać addytywną nefrotoksyczność z niektórymi chemioterapeutykami [35].

\section{Postępowanie w szczególnych sytuacjach klinicznych Profilaktyczne stosowanie antybiotyków u chorych z neutropeniq}

Profilaktyczne stosowanie antybiotyków zaleca się przede wszystkim u chorych z grupy wysokiego ryzyka wystąpienia powikłań infekcyjnych, gdy można spodziewać się ciężkiej neutropenii [bezwzględna liczba neutrofili (ANC - absolute neutrophil count) $\leq 100 / \mathrm{mm}^{3}$ przez co najmniej 
7 dni] [18-19,72-73]. Zaleca się stosowanie fluorochinolonów - ciprofloksacyny w dawce $2 \times 500 \mathrm{mg}$ p.o. lub lewofloksacyny w dawce $1 \times 500 \mathrm{mg}$ p.o. [73]. Celem tak prowadzonej profilaktyki jest przede wszystkim zmniejszenie częstości występowania zakażeń pałeczkami Gram-ujemnymi. Dostępne wyniki badań wskazują na to, że prowadzenie profilaktyki z zastosowaniem fluorochinolonów jest skuteczne (w tym zmniejsza całkowitą śmiertelność), choć nie jest jasne, czy nie zwiększa częstości występowania zakażeń szczepami opornymi na tę grupę leków [9,74]. Nie ma przy tym precyzyjnych danych na temat skuteczności profilaktyki fluorochinolonami w Polsce. Niestety, odsetki oporności wśród bakterii Gram-ujemnych są w naszym kraju niezwykle wysokie - dane z ECDC za rok 2013 wskazują, że opornych na fluorochinolony jest prawie 30\% izolatów E. coli i P. aeruginosa oraz ponad 70\% izolatów K. pneumoniae [75]. Przyjmuje się, że jeżeli odsetek szczepów opornych jest większy niż $20 \%$, to skuteczność profilaktyki jest zmniejszona, brak jest jednak zaleceń co do stosowania alternatywnych antybiotyków [76]. W przypadku chorych ze znacznym ryzykiem wystąpienia zapalenia płuc spowodowanego przez Pneumocystis jirovecii (przede wszystkim chorzy otrzymujący znaczne dawki sterydów $-\geq 16 \mathrm{mg}$ prednizolonu lub $\geq 4$ mg deksametazonu przez ponad miesiąc, poddawani przeszczepom komórek krwiotwórczych albo leczeni analogami puryn) należy rozważyć profilaktykę z użyciem kotrymoksazolu. Nie został ustalony optymalny schemat dawkowania kotrymoksazolu w profilaktyce, najczęściej stosowane schematy to 480-960 mg raz dziennie lub 960 mg 3 razy w tygodniu [77]. Taką profilaktykę prowadzi się również wiele miesięcy po zakończeniu leczenia onkologicznego [78].

W przypadku chorych z wysokim ryzykiem zakażeń grzybiczych można stosować profilaktykę przeciwgrzybiczą - skierowaną przeciwko drożdżom lub pleśniom. Dotyczy to prawie wyłącznie chorych na nowotwory układu krwiotwórczego.

\section{Empiryczna antybiotykoterapia chorych z gorq̨czkq neutropenicznq}

U wszystkich chorych z gorączką neutropeniczną istnieją wskazania do empirycznej antybiotykoterapii, którą należy wdrożyć niezwłocznie. W każdym przypadku należy dążyć do ustalenia zarówno etiologii gorączki neutropenicznej, jak i czynnika zakaźnego, który ją wywołał. Zgodnie z wytycznymi u wybranych chorych z grupy niskiego ryzyka istnieje, przy zachowaniu szczególnej ostrożności (i spełnieniu pewnych uwarunkowań społecznych i organizacyjnych), możliwość leczenia doustnego w warunkach ambulatoryjnych $[18,19,79]$. Większość chorych wymaga jednak antybiotykoterapii szpitalnej. Ryzyko powikłań gorączki neutropenicznej ocenia się zazwyczaj w skali Multinational
Tabela IV. Skala MASCC do oceny ryzyka powikłań u chorych, u których wystąpiła gorączka neutropeniczna [80]

\begin{tabular}{lc}
\hline Cecha & $\begin{array}{c}\text { Liczba } \\
\text { punktów }\end{array}$ \\
\hline $\begin{array}{l}\text { pogorszenie stanu klinicznego związane } \\
\text { z gorączką neutropeniczną }\end{array}$ & \\
$\quad$ - niewielkie & 3 \\
$\quad$ - brak & 5 \\
skurczowe ciśnienie krwi > $90 \mathrm{~mm}$ Hg & 5 \\
$\begin{array}{l}\text { bez przewlekłej obturacyjnej choroby } \\
\text { płuc w wywiadzie }\end{array}$ & 4 \\
nowotwór lity lub hematologiczny, \\
bez wywiadu zakażeń grzybiczych \\
$\begin{array}{l}\text { bez odwodnienia wymagającego } \\
\text { dożylnej podaży płynów } \\
\text { chory ambulatoryjny } \\
\text { wiek < } 60 \text { lat }\end{array}$ \\
\hline
\end{tabular}

Association of Supportive Care in Cancer (MASCC) [80]. Skalę MASCC przedstawiono $w$ tabeli IV. Wynik < 21 punktów pozwala zidentyfikować chorych obarczonych małym ryzykiem powikłań. W takim przypadku zalecane schematy antybiotykoterapii ambulatoryjnej opierają się przede wszystkim na połączeniu doustnego fluorochinolonu i amoksycyliny z kwasem klawulanowym (albo klindamycyną - w przypadku uczulenia na penicylinę i pochodne). Ze względu na wspomnianą już powszechną oporność pałeczek Gram-ujemnych na fluorochinolony stosowanie takiego schematu leczenia w warunkach polskich wydaje się dyskusyjne. Schematy leczenia antybiotykami dożylnymi gorączki neutropenicznej obejmują [18-19,73,79]:

- antybiotyk $\beta$-laktamowy o aktywności wobec Pseudomonas aeruginosa. Wielu autorów nie zaleca aktualnie w tej sytuacji klinicznej stosowania ceftazydymu ani cefepimu w monoterapii, ze względu na narastającą oporność i słabszą aktywność wobec bakterii Gram-dodatnich. Dla uniknięcia nadużywania karbapenemów wydaje się, że piperacylina z tazobaktamem stanowi $\mathrm{w}$ tej grupie chorych rozsądny kompromis. W tabeli V przedstawiono dane z 2013 roku na temat oporności na wyżej wymienione antybiotyki niektórych bakterii Gram-ujemnych;

- w przypadku chorych z grupy wysokiego ryzyka (np. ciężki przebieg kliniczny, obecność linii naczyniowej, informacje na temat kolonizacji MRSA, objawy zakażenia tkanek miękkich lub zapalenia płuc) należy dołączyć do leczenia antybiotyk aktywny wobec metycylinoopornych gronkowców (wankomycynę, teikoplaninę lub linezolid);

- w przypadku chorych z biegunką należy przeprowadzić diagnostykę w kierunku szczepów Clostridium difficile, produkujących toksyny; 
Tabela V. Oporność niektórych bakterii Gram-ujemnych na antybiotyki stosowane w empirycznym leczeniu gorączki neutropenicznej

\begin{tabular}{lccc}
\hline \multirow{2}{*}{ Bakteria } & \multicolumn{3}{c}{ Odsetek szczepów niewrażliwych } \\
\cline { 2 - 4 } & Cefalosporyny III generacji & Karbapenemy & Aminoglikozydy \\
\hline Escherichia coli & $12 \%$ & $0 \%$ & $13 \%$ \\
Klebsiella pneumoniae & $66 \%$ & $1 \%$ & $60 \%$ \\
Pseudomonas aeruginosa & $33 \%^{*}$ & $36 \%$ & $30 \%$ \\
\hline
\end{tabular}

* W przypadku Pseudomonas podano odsetek szczepów niewrażliwych na ceftazydym. Oporność Pseudomonas aeruginosa na piperacylinę z tazobaktamem wynosiła $24 \%$. Dane za 2013 rok, za ECDC (http://ecdc.europa.eu/en/healthtopics/antimicrobial_resistance/database/Pages/database.aspx).

Tabela VI. Typowy czas antybiotykoterapii w niektórych schorzeniach występujących u chorych na nowotwory [73, 95]

\begin{tabular}{ll}
\hline Schorzenie & Typowy czas leczenia \\
\hline pozaszpitalne zapalenie płuc & Streptococcus pneumoniae $-7 \mathrm{dni}$ \\
szpitalne zapalenie płuc* & pozostałe drobnoustroje $-14 \mathrm{dni}$ \\
& typowo 7-14 dni \\
zakażenia dróg moczowych & pałeczki niefermentujące (np. Pseudomonas) $-14-21 \mathrm{dni}$ \\
zakażenia krwi związane z krótkoterminowymi dostępami do żył centralnych & 7-14 dni \\
& gronkowce koagulazo-ujemne $-5-7$ dni, jeżeli wkłucie usunięto, \\
& 7-10 dni przy pozostawieniu wkłucia \\
& Staphylococcus aureus - co najmniej 14 dni \\
& bakterie Gram-ujemne $-7-14$ dni \\
\hline
\end{tabular}

*Istnieją dane sugerujące możliwość skrócenia leczenia, ale pochodzą one z badań nieobejmujących chorych onkologicznych [96].

- w przypadku podejrzenia zakażenia wewnątrzbrzusznego zaleca się dołączenie leku o aktywności wobec bakterii beztlenowych (metronidazol);

- nie zaleca się rutynowego stosowania łączonej antybiotykoterapii, o ile nie występują do tego szczególne wskazania kliniczne. Wyniki metaanalizy Cochrane z 2013 roku sugerują pogorszenie wyników leczenia u chorych otrzymujących antybiotyki $\beta$-laktamowe wraz z aminoglikozydami, w porównaniu z chorymi leczonymi tylko antybiotykami $\beta$-laktamowymi [43]. Również rutynowe dodawanie do antybiotyku $\beta$-laktamowego glikopeptydu u wszystkich chorych nie poprawia wyników leczenia [81];

- w przypadku zakażeń związanych z cewnikami naczyniowymi należy postępować zgodnie z odpowiednimi protokołami, ustalając przede wszystkim wskazania do usunięcia cewnika [82];

- w przypadku chorych na zapalenie płuc należy dołączyć antybiotyk mający w swoim spektrum drobnoustroje atypowe - w pierwszej kolejności makrolid [83]. U chorych z grup ryzyka zakażenia Pneumocystisjirovecii należy przeprowadzić diagnostykę w tym kierunku;

- należy rozważyć wskazania do empirycznego stosowania leków przeciwgrzybiczych.

Jeżeli rozpoznano przyczynę gorączki, leczenie należy kontynuować tak długo, jak to wynika z zaleceń dla poszczególnych schorzeń (vide tabela VI), nie przerywając go jednak,

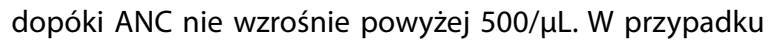

gdy przyczyny gorączki nie ustalono, lecz chory dobrze odpowiedział na leczenie, można je zakończyć, gdy ANC wzrośnie powyżej 500/ $\mu \mathrm{L}$ [19]. Jeżeli chory nie gorączkuje przez 5-7 dni, leczenie można zakończyć nawet u chorych z ANC < 500/ $\mu \mathrm{L}$, chyba że występują dodatkowe czynniki ryzyka, w takiej sytuacji sugeruje się wydłużenie antybiotykoterapii do $10 \mathrm{dni}$ [18].

Typowo można oczekiwać ustąpienia gorączki średnio po 2 dobach leczenia u chorych na nowotwory lite i po 5 dobach u chorych onkohematologicznych [19]. Brak poprawy po takim okresie leczenia stwarza konieczność ponowienia oceny chorego i włączenia leczenia przeciwgrzybiczego. Należy również rozważyć zmianę antybiotykoterapii. Brak jest jednoznacznych zaleceń co do wyboru antybiotyków drugiego rzutu, często polecanym schematem jest połączenie karbapenemu (ale nie ertapenemu — ze względu na brak aktywności wobec Pseudomonas aeruginosa) $z$ antybiotykiem aktywnym wobec MRSA. Chorzy, którzy źle odpowiadają na wstępne leczenie, stanowią grupę o wysokiej śmiertelności, dlatego należy dążyć do uzyskania u tych chorych konsultacji lekarza o dużym doświadczeniu w leczeniu chorych onkologicznych z zakażeniami [18].

\section{Profilaktyka antybiotykowa u chorych z wodobrzuszem}

W przypadku chorych z wodobrzuszem nowotworowym, u których wystąpił epizod spontanicznego zapalenia otrzewnej, zaleca się stosowanie profilaktyki antybiotyko- 
wej, norfloksacyny w dawce $400 \mathrm{mg} 1 \mathrm{raz}$ dziennie [73]. Brak jest wiarygodnych danych na temat profilaktyki antybiotykowej u chorych z wodobrzuszem nowotworowym, bez cech marskości wątroby, krwawienia w przewodu pokarmowego ani uprzednich epizodów zapalenia otrzewnej [84, 85].

\section{Podsumowanie}

Pomimo napotykanych trudności w znakomitej większości przypadków chorych onkologicznych zakażonych bakteryjnie można uzyskać wyleczenie. Prawidłowe i staranne prowadzenie antybiotykoterapii poprawia wyniki leczenia, zmniejsza jego koszty, skraca czas pobytu chorych w szpitalach oraz zapobiega nasilaniu się zjawiska lekooporności drobnoustrojów.

\section{Lista stosowanych skrótów:}

ANC - bezwzględna liczba neutrofili,

ECDC - European Centre for Disease Prevention and Control, ESBL $-\beta$-laktamazy o rozszerzonym spektrum substratowym,

ESMO - European Society for Medical Oncology,

EUCAST - European Committee on Antimicrobial Susceptibility Testing,

HLGR — oporność na gentamycynę wysokiego stopnia,

IDSA — Infectious Diseases Society of America,

KORLD — Krajowy Ośrodek Referencyjny do spraw Lekowrażliwości Drobnoustrojów,

$\mathrm{MBL}$ - metalo- $\beta$-laktamazy,

MIC — minimalne stężenie hamujące wzrost drobnoustroju,

$\mathrm{MLS}_{B}$ - mechanizm oporności na markolidy, linkozaminy i streptograminy B związany z aktywacją genu erm kodującego metylazę,

MRSA - metycylinooporny gronkowiec złocisty,

MRCoNS - metycylinooporne gronkowce koagulazo-ujemne, MSSA - metycylinowrażliwy gronkowiec złocisty, MSCoNS - metycylinowrażliwe gronkowce koagulazo-ujemne.

\section{Konflikt interesów: nie zgłoszono}

\section{Dr n. med. Łukasz R. Nowak}

Oddział Anestezjologii i Intensywnej Terapii

Kliniki Chirurgii Onkologicznej

Centrum Onkologii —Instytut im. Marii Skłodowskiej-Curie,

Oddział w Krakowie

ul. Garncarska 11, 31-115 Kraków

e-mail:Ilukasz@interia.pl

Otrzymano: 15 września 2015 r.

Przyjęto do druku: 23 marca $2016 r$.

\section{Piśmiennictwo}

1. Khorana AA, Francis CW, Culakova E i wsp. Thromboembolism is a leading cause of death in cancer patients receiving outpatient chemotherapy. J Thromb Haemost 2007; 5: 632-634.
2. Taha A, Vinograd I, Sakhnini A i wsp. The association between infections and chemotherapy interruptions among cancer patients: prospective cohort study. J Infect 2015; 70: 223-229.

3. Hammuda A, Hayder S, Elazzazy S i wsp. Point prevalence survey of antimicrobial utilization in oncology patients. J Infect Dev Ctries 2013; 7: 990-993.

4. Seaton RA, Nathwani D, Burton P i wsp. Point prevalence survey of antimicrobial use in Scottish hospitals utilizing the Glasgow Antimicrobial Audit Tool (GAAT). Int J Antimicrob Agents 2007; 29: 693-699.

5. Khan A, Raza S, Batul SA i wsp. The evolution of Clostridium difficile infection in cancer patients: epidemiology, pathophysiology, and guidelines for prevention and management. Recent Pat Antiinfect Drug Discov 2012; 7: 157-170.

6. Cantón R, Horcajada JP, Oliver A i wsp. Inappropriate use of antibiotics in hospitals: the complex relationship between antibiotic use and antimicrobial resistance. Enferm Infecc Microbiol Clin 2013; 31 Suppl 4:3-11.

7. Davey P, Brown E, Charani E i wsp. Interventions to improve antibiotic prescribing practices for hospital inpatients. Cochrane Database Syst Rev 2013; 4: CD003543

8. Baden LR, Bensinger W, Casper C i wsp. Prevention and treatment of cancer-related infections. JNCCN 2012; 10: 1412-1445.

9. Gafter-Gvili A, Fraser A, Paul M i wsp. Antibiotic prophylaxis for bacterial infections in afebrile neutropenic patients following chemotherapy. Cochrane Database Syst Rev 2012; 1: CD004386.

10. Jackowska T, Grzelczyk-Wielgórska M, Lewicka D. Szczepienia ochronne u pacjentów z chorobą nowotworową. Postępy Nauk Medycznych 2014; 27: 23-27.

11. Rubin LG, Levin MJ, Ljungman P i wsp. 2013 IDSA clinical practice guideline for vaccination of the immunocompromised host. Clin Infect Dis 2014; 58: e44-100.

12. Komunikat Głównego Inspektora Sanitarnego z dnia 16 października 2015 r. w sprawie Programu Szczepień Ochronnych na rok 2016 http:// dziennikmz.mz.gov.pl/DUM_MZ/2015/63/akt.pdf.

13. Rubin LG, Schaffner W. Clinical practice. Care of the asplenic patient. N Engl J Med 2014; 371: 349-356.

14. Davies JM, Lewis MP, Wimperis J i wsp. Review of guidelines for the prevention and treatment of infection in patients with an absent or dysfunctional spleen: prepared on behalf of the British Committee for Standards in Haematology by a working party of the Haemato-Oncology task force. Br J Haematol 2011: 155: 308-317.

15. Kuchar E, Miśkiewicz K, Karlikowska M. A review of guidance on immunization in persons with defective or deficient splenic function. Br J Haematol 2015; 171: 683-694.

16. Ferrer R, Martin-Loeches I, Phillips G i wsp. Empiric antibiotic treatment reduces mortality in severe sepsis and septic shock from the first hour: results from a guideline-based performance improvement program. Crit Care Med 2014; 42: 1749-1755.

17. Ko BS, Ahn S, Lee YS i wsp. Impact of time to antibiotics on outcomes of chemotherapy-induced febrile neutropenia. Support Care Cancer 2015; 23: 2799-2804.

18. de Naurois J, Novitzky-Basso I, Gill MJ i wsp. Management of febrile neutropenia: ESMO Clinical Practice Guidelines. Ann Oncol 2010; 21 (Suppl 5): 252-256.

19. Freifeld AG, Bow EJ, Sepkowitz KA. Clinical practice guideline for the use of antimicrobial agents in neutropenic patients with cancer: 2010 update by the Infectious Diseases Society of America. CID 2011; 52: e56-93.

20. Masterton RG. Antibiotic de-escalation. Crit Care Clin 2011; 27: 149-162.

21. Mokart D, Slehofer G, Lambert J i wsp. De-escalation of antimicrobial treatment in neutropenic patients with severe sepsis: results from an observational study. Intensive Care Med 2014; 40: 41-49.

22. European Committee on Antimicrobial Susceptibility Testing. Breakpoints tables for interpretation of MICs and zones diameters. Version 5.0, 2015. http://www.eucast.org.

23. Stein GE, Schooley S. Urinary concentrations and bactericidal activities of newer fluoroquinolones in healthy volunteers. Int J Antimicrob Agents 2004; 24: 168-172.

24. Goulenok T, Fantin B. Antimicrobial treatment of febrile neutropenia: pharmacokinetic-pharmacodynamic considerations. Clin Pharmacokinet 2013; 52: 869-883.

25. Shiu J, Wang E, Tejani AM i wsp. Continuous versus intermittent infusions of antibiotics for the treatment of severe acute infections. Cochrane Database Syst Rev 2013; 3: CD008481.

26. MacKenzie FM, Gould IM. The post-antibiotic effect. J Antimicrob Chemother 1993; 32: 519-537.

27. Narodowy Instytut Leków. Sprawozdanie z realizacji Narodowego Programu Ochrony Antybiotyków. Warszawa 2011. 
28. Naughton C, Hennessy Y, Mannion C i wsp. A comparison of antibiotic point prevalence survey data from four Irish regional/general hospitals. Ir J Med Sci 2011; 180: 457-461.

29. Haeseker M, Havenith T, Stolk L i wsp. Is the standard dose of amoxicillin-clavulanic acid sufficient? BMC Pharmacol Toxicol 2014; 15: 38

30. Spyker DA, Rugloski RJ, Vann RL i wsp. Pharmacokinetics of amoxicillin: dose dependence after intravenous, oral, and intramuscular administration. Animicrob Agent Chemother 1977; 1: 132-141.

31. Pagkalis S, Mantadakis E, Mavros MN i wsp. Pharmacological considerations for the proper clinical use of aminoglycosides. Drugs 2011; 71: 2277-2294.

32. Stankowicz MS, Ibrahim J, Brown DL. Once-daily aminoglycoside dosing: An update on current literature. Am J Health Syst Pharm 2015; 72: 1357-1364.

33. Mavros MN, Polyzos KA, Rafailidis PI i wsp. Once versus multiple daily dosing of aminoglycosides for patients with febrile neutropenia: a systematic review and meta-analysis. J Antimicrob Chemother 2011; 66: 251-259.

34. Stabler SN, Ensom MH. Extended-interval aminoglycoside therapy for adult patients with febrile neutropenia: a systematic review. Can J Hosp Pharm 2011; 64: 182-191.

35. Keller F, Schroppel B, Ludwig U. Pharmacokinetic and pharmacodynamic considerations of antimicrobial drug therapy in cancer patients with kidney dysfunction. World J Nephrol 2015; 4: 330-344.

36. Tsai D, Lipman J, Roberts JA. Pharmacokinetic/pharmacodynamic considerationsfor the optimization of antimicrobial delivery in the critically ill. Curr Opin Crit Care 2015; 21: 412-420.

37. Albrich WC, Harbarth S. Pros and cons of using biomarkers versus clinical decisions in start and stop decisions for antibiotics in the critical care setting. Intensive Care Med 2015; 41: 1739-1751.

38. Rubinstein E, Keynan Y. Vancomycin revisited -60 years later. Front Public Health 2014; 31: 217.

39. Nemeth J, Oesch G, Kuster SP. Bacteriostatic versus bactericidal antibiotics for patients with serious bacterial infections: systematic review and meta-analysis. J Antimicrob Chemother 2015; 70: 382-395.

40. Bollenbach T. Antimicrobial interactions: mechanisms and implications for drug discovery and resistance evolution. Curr Opin Microbiol 2015; 27: 1-9.

41. Olajuyigbe OO. Synergistic influence of tetracycline on the antibacterial activities of amoxicillin against resistant bacteria. J Pharm Allied Health Sci 2012; 2: 12-20.

42. Paul M, Lador A, Grozinsky-Glasberg S i wsp. Beta lactam antibiotic monotherapy versus beta lactam-aminoglycoside antibiotic combination therapy for sepsis. Cochrane Database Syst Rev 2014; 1: CD003344.

43. Paul $M$, Dickstein $Y$, Schlesinger A i wsp. Beta-lactam versus beta-lactam-aminoglycoside combination therapy in cancer patients with neutropenia. Cochrane Database Syst Rev 2013; 6: CD003038.

44. Al-Anazi KA, Al-Jasser AM. Infections caused by Acinetobacter baumannii in recipients of hematopoietic stem cell transplantation. Front Oncol 2014; 4: 1-10.

45. Sánchez MB. Antibiotic resistance in the opportunistic pathogen Stenotrophomonas maltophilia. Front Microbiol 2015; 6: 1-7.

46. Amaral L, Spengler G, Martins A i wsp. Inhibitors of bacterial efflux pumps that also inhibit efflux pumps of cancer cells. Anticancer Res 2012; 32: 2947-2957.

47. Opperman TJ, Nguyen ST. Recent advances toward a molecular mechanism of efflux pump inhibition. Front Microbiol 2015; 6: 421.

48. Fair RJ, Tor Y. Antibiotics and bacterial resistance in the 21 st century. Perspect Med Chem 2014; 6: 25-64.

49. Bush K. Bench-to-bedside review: The role of $\beta$-lactamases in antibiotic-resistant Gram-negative infections. Crit Care 2010; 14: 224.

50. Skrzypek K, Malm A. Oporność bakterii na karbapenemy w aspekcie zdrowia publicznego. Zdr Publ 2012; 122: 201-205.

51. Dortet L, Poirel L, Nordmann P. Worldwide dissemination of the NDM-type carbapenemases in Gram-negative bacteria. Biomed Res Int 2014; 2014: Article ID 249856

52. Nikonorow E, Baraniak A, Gniadkowski M. Oporność bakterii z rodziny Enterobacteriaceae na antybiotyki $\beta$-laktamowe wynikająca z wytwarzania $\beta$-laktamaz. Post Mikrobiol 2013; 52: 261-271.

53. Jacoby GA. AmpC $\beta$-lactamases. Clin Microbiol Rev 2009; 22: 161-182.

54. Abbas A, Srivastava P, Nirwan PS. Prevalence of MLSB resistance and observation of erm A \& erm C genes at a tertiary care hospital. J Clin Diagn Res 2015; 9: DC08-10.

55. Stapleton PD, Taylor PW. Methicillin resistance in Staphylococcus aureus: mechanisms and modulation. Sci Prog. 2002; 85: 57-72.
56. Ghamrawi RJ, Neuner E, Rehm SJ. Ceftaroline fosamil: A super-cephalosporin? Cleve Clin J Med 2015; 82: 437-444.

57. Paladino JA, Jacobs DM, Shields RK i wsp. Use of ceftaroline after glycopeptide failure to eradicate meticillin-resistant Staphylococcus aureus bacteraemia with elevated vancomycin minimum inhibitory concentrations. Int J Antimicrob Agents 2014; 44: 557-563.

58. Kehrmann J, Kaase M, Szabados F i wsp. Vancomycin MIC creep in MRSA blood culture isolates from Germany: a regional problem? Eur J Clin Microbiol Infect Dis 2011; 30: 677-683.

59. Fernandes P.The global challenge of new classes of antibacterial agents: an industry perspective. Curr Opin Pharmacol 2015; 24: 7-11.

60. Gwynn MN, Portnoy A, Rittenhouse SF i wsp. Challenges of antibacterial discovery revisited. Ann N Y Acad Sci 2010; 1213: 5-19.

61. The $10 x^{\prime} 20$ Initiative: pursuing a global commitment to develop 10 new antibacterial drugs by 2020. Clin Infect Dis 2010; 50: 1081-1083.

62. WHO. Antimicrobial resistance. Global report on Surveillance. World Health Organization 2014.

63. Economou V, Gousia P. Agriculture and food animals as a source of antimicrobial-resistant bacteria. Infect Drug Resist 2015; 8: 49-61.

64. Botev R, Mallié JP, Wetzels JF i wsp. The clinician and estimation of glomerular filtration rate by creatinine-based formulas: current limitations and quo vadis. Clin J Am Soc Nephrol 2011; 6: 937-950.

65. Riechelmann RP, Del Giglio A. Drug interactions in oncology: how common are they? Ann Oncol 2009; 20: 1907-1912.

66. Wijnen PA, Op den Buijsch RA, Drent M i wsp. Review article: The prevalence and clinical relevance of cytochrome $P 450$ polymorphisms. Aliment Pharmacol Ther 2007; 26 Suppl 2: 211-219.

67. Gillman PK. Monoamine oxidase inhibitors, opioid analgesics and serotonin toxicity. Br J Anaesth 2005; 95: 434-441.

68. Ramsey TD, Lau TT, Ensom MH. Serotonergic and adrenergic drug interactions associated with linezolid: a critical review and practical management approach. Ann Pharmacother 2013; 47: 543-560.

69. Fralick M, Macdonald EM, Gomes T i wsp. Co-trimoxazole and sudden death in patients receiving inhibitors of renin-angiotensin system: population based study. BMJ 2014; 349: g6196.

70. Antoniou T, Hollands S, Macdonald EM i wsp. Trimethoprim-sulfamethoxazole and risk of sudden death among patients taking spironolactone. CMAJ 2015; 187: E138-143.

71. Hale SF, Lesar TS. Interaction of vitamin K antagonists and trimethoprim-sulfamethoxazole: ignore at your patient's risk. Drug MetabolDrug Interact 2014; 29: 53-60.

72. Villafuerte-Gutierrez $P$, Villalon L, Losa JE i wsp. Treatment of febrile neutropenia and prophylaxis in hematologic malignancies: a critical review and update. Adv Hematol 2014; 2014: 986938.

73. Narodowy Program Ochrony Antybiotyków: Rekomendacje diagnostyki, terapii i profilaktyki antybiotykowej zakażeń w szpitalu. Red. Hryniewicz W i Ozorowski T. Narodowy Instytut Leków, Warszawa 2015.

74. Garnica M, Nouér SA, Pellegrino FL i wsp. Ciprofloxacin prophylaxis in high risk neutropenic patients: effects on outcomes, antimicrobial therapy and resistance. BMC Infect Dis 2013; 13: 356.

75. http://ecdc.europa.eu/en/healthtopics/antimicrobial_resistance/ database/Pages/database.aspx.

76. Bow EJ. Fluoroquinolones, antimicrobial resistance and neutropenic cancer patients. Curr Opin Infect Dis 2011; 24: 545-553.

77. Cooley L, Dendle C, Wolf J i wsp. Consensus guidelines for diagnosis, prophylaxis and management of Pneumocystis jirovecii pneumonia in patients with haematological and solid malignancies, 2014. Intern Med J 2014; 44: 1350-1363.

78. Roliński J, Pasiarski M, Hus I i wsp. Profilaktyka i leczenie zakażeń u chorych na przewlekłą białaczkę limfocytowa. Acta Haematol Polonica 2013; 44: 99-103.

79. Flowers CR, Seidenfeld J, Bow EJ i wsp. Antimicrobial prophylaxis and outpatient management of fever and neutropenia in adults treated for malignancy: American Society of Clinical Oncology clinical practice guideline. J Clin Oncol 2013; 31:794-810.

80. Klastersky J, Paesmans M, Rubenstein EB i wsp. The Multinational Association for Supportive Care in Cancer risk index: A multinational scoring system for identifying low-risk febrile neutropenic cancer patients. J Clin Oncol 2000; 18: 3038-3051.

81. Paul $M$, Dickstein $Y$, Borok S i wsp. Empirical antibiotics targeting Gram-positive bacteria for the treatment of febrile neutropenic patients with cancer. Cochrane Database Syst Rev 2014;1:CD003914.

82. Mermel LA, Allon M, Bouza Ei iwsp.Clinical practice guidelines for the diagnosis and management of intravascular catheter-related infection:2009 Update by the Infectious Diseases Society of America. Clin Infect Dis 2009; 49:1-45. 
83. Lee JS, Giesler DL, Gellad WF i wsp. Antibiotic therapy for adults hospitalized with community-acquired pneumonia: a systematic review. JAMA 2016; 315: 593-602.

84. Enzler MJ, Berbari E, Osmon DR. Antimicrobial prophylaxis in adults. Mayo Clin Proc 2011; 86: 686-701.

85. Kucharska M, Simon K. Algorytmy diagnostyki i terapii u pacjenta z wodobrzuszem w przebiegu marskości wątroby. Hepatologia 2014; 14: 26-33.

86. Gea-Banacloche J, Segal BH. Infections in the cancer patient. W: DeVita VD, Lawrence TS, Rosenberg SA (red.) Cancer principles and practice of oncology. Philadelphia: Lippincott, Williams and Wilkins, 2011: 2262-2299.

87. Donnelly JP, Blijlevens NMA, van der Velden WJFM. Host impairments in patients with neoplastic diseases. W: Stosor V i Zembower TR (red.): Infectious Complications in Cancer Patients. Cham: Springer, 2014

88. Adembri C, Novelli A. Pharmacokinetic and pharmacodynamic parameters of antimicrobials: potential for providing dosing regimens that are less vulnerable to resistance. Clin Pharmacokinet 2009; 48: 517-528.
89. Brown GR. Cotrimoxazole-optimal dosing in the critically ill. Ann Intensive Care 2014; 4: 13.

90. Martinez MN, Papich MG, Drusano GL. Dosing regimen matters: the importance of early intervention and rapid attainment of the pharmacokinetic/pharmacodynamic target. Antimicrob Agents Chemother 2012; 56: 2795-2805.

91. Nation RL, Li J. Colistin in the 21st century. Curr Opin Infect Dis 2009; 22: 535-543.

92. Roberts JA, Norris R, Paterson DL i wsp. Therapeutic drug monitoring of antimicrobials. Br J Clin Pharm 2012; 73: 27-36.

93. Rybak MJ. The pharmacokinetic and pharmacodynamic properties of vancomycin. Clin Infect Dis 2006; 42 (Suppl 1): S35-S39.

94. Kappel J, Calissi P. Nephrology: 3. Safe drug prescribing for patients with renal insufficiency. CMAJ 2002; 166: 473-477.

95. Anderson EJ. Respiratory infections. W: Stosor V i Zembower TR (red.): Infectious Complications in Cancer Patients. Cham: Springer 2014.

96. Pugh R, Grant C, Cooke RP i wsp. Short-course versus prolonged-course antibiotic therapy for hospital-acquired pneumonia in critically ill adults. Cochrane Database Syst Rev 2015; 8: CD007577. 